\title{
Trade Mark Protection for Smells, Tastes and Feels - Critical Analysis of Three Non-Visual Signs in the EU
}

\author{
Simon Geiregat $(\mathbb{D}$
}

Accepted: 1 February 2022/Published online: 2 March 2022

(C) The Author(s) 2022

\begin{abstract}
This article focuses on the ability to protect three non-traditional signs as trade marks in the EU: smell (olfactory marks), taste (gustatory marks) and feel (tactile marks). All three types of subject matter can meet the definition of a sign. According to the majority view in literature and practice, none of the three can currently be represented on the register with sufficient clarity and precision, however. It is argued that the veracity of that finding essentially boils down to a lack of vocabulary and IT solutions, and that it depends on the level of detail that can be expected from non-visual signs. Theoretically, distinctiveness is less of an obstacle to protection. Although some signs need to acquire distinctiveness through use, distinctiveness should be assessed on a case-by-case basis and it cannot be excluded that there are smells, tastes and feels that are inherently distinct. In practice, authorities seem to uphold excessive thresholds for olfactory, gustatory, and especially tactile marks. This is understandable in the light of their potential scope, which lies at the heart of the debate on their eligibility for protection. Indeed, granting protection to these three types of signs carries the risk of depleting and propertising almost anything. Although this might be true, it is contended that more research is needed and that there is no legislative basis for a Freihaltebedürfnis (need to keep signs freely available) in this respect. After considering fundamental rights and public policy as alternative means of channelling that concern, the article concludes that it is for the EU legislator to evaluate whether to exclude certain signs from trade mark law.
\end{abstract}

Simon Geiregat is a Postdoctoral Researcher in intellectual property and digital law at the FWO Research Foundation - Flanders, Ghent University, Belgium. He is an Assistant Professor at the Universiteit Leiden, The Netherlands. He is also a Postdoctoral Fellow at the Max Planck Institute for Innovation and Competition, Munich, Germany.

S. Geiregat $(\bowtie)$

Ph.D.; Postdoctoral Researcher in intellectual property and digital law at the FWO Research

Foundation - Flanders, Ghent University, Ghent, Belgium

e-mail: simon.geiregat@ugent.be

URL: https://www.geiregat.com 
Keywords Trade marks $\cdot$ Non-traditional $\cdot$ Olfactory $\cdot$ Gustatory $\cdot$ Tactile $\cdot$ Haptic

\section{Introduction}

Over the last few decades, economic actors have increasingly been trying to acquire trade mark rights to a broad variety of non-traditional signs, i.e. signs that do not exclusively consist of letters, numerals, words, typographic characters, images, stylisation, layout, or graphic features. For visual signs, those attempts have largely proven fruitful in the European Union (EU). Colour marks, shape marks, sound marks and pattern and position marks are prime examples of non-traditional marks that have become so common in contemporary trade that it is even questionable to what extent they can still be called non-traditional. ${ }^{1}$

Now that the 2015 Trade Mark Reform Package is completely operational and the EU Intellectual Property Network (EUIPN) has published its Common Practice on New Types of Marks, ${ }^{2}$ this article focuses on three non-visual signs that have enjoyed little attention lately. It critically analyses the possibility of acquiring trade mark protection for an odour, smell, scent, fragrance, or aroma (olfactory marks), for a taste (gustatory marks), and for a feeling, a touch or "the feel" of something (tactile marks, also referred to as haptic or sensory marks). In the next few pages, these types of subject matter are first tested against the criteria for trade mark protection (Sect. 2), after which their potential scope of protection is explained (Sect. 3). Subsequently, this article is wrapped up with some remarks (Sect. 4). Over these chapters, the state of the law will be assessed de lege lata as well as de lege ferenda, and particular attention will be drawn to the differential treatments of the variety of non-traditional marks.

\section{Criteria for Protection}

Trade mark law in the EU is characterised by its dual nature. On the one hand, there is the regime of national (including Benelux) trade marks, substantially harmonised by the 2015 Trade Mark Directive. ${ }^{3}$ On the other hand, there is the regime of EU trade marks with unitary effect, currently governed by the EU Trade Mark Regulation, recast in $2017 .^{4}$ Despite the mantra that the latter regime is an

\footnotetext{
${ }^{1}$ Schneider (2018), para. 30.

2 EUIPN (April 2021) Common Communication. New Types of Marks: Examination of Formal Requirements and Grounds for Refusal. CP11. https://euipo.europa.eu/tunnel-web/secure/webdav/guest/ document_library/contentPdfs/EUIPN/CP11/common_communication_cp11_en.pdf. Accessed 9 September 2021.

${ }^{3}$ Directive (EU) 2015/2436 (EP \& Council) to approximate the laws of the Member States relating to trade marks (recast) [2015] OJ L 336/1 ("TM Directive").

${ }^{4}$ Regulation (EU) 2017/1001 (EP \& Council) on the European Union trade mark (codification) [2017] OJ L 154/1 ("EUTM Regulation").
} 
"autonomous system", applied "independently of any national system", 5 the CJEU interprets the protection criteria in the Directive and in the Regulation identically. Moreover, the harmonisation objective of the Directive implies that the nature of the signs of which a trade mark may consist cannot differ from one Member State to another. ${ }^{6}$ Accordingly, the CJEU has the final word on the protection criteria for both EU and national trade marks.

The Trade Mark Directive and the EU Trade Mark Regulation impose the same cumulative criteria for trade mark protection. First, the subject matter must constitute a sign in order to be a trade mark (Sect. 2.1). Second, it must be capable of being represented on the trade mark register (Sect. 2.2). Third, it should be capable of distinguishing the goods or services of one undertaking from those of other undertakings (Sect. 2.3). ${ }^{7}$ In the following chapters, these three requirements are applied to odours, tastes and feels, respectively.

\subsection{Sign}

The condition of a sign is defined in neither international nor European legislation. Nonetheless, it appears from CJEU case-law that a "sign" must, at a bare minimum, be able to "convey a[ny] meaning". 8 This requirement seems to match up with semantic theory, which broadly defines a sign as "something which stands to somebody for something in some respect or capacity".?

Within the context of trade marks, the concept of a sign is more restrictive. Going one step further, a sign must be sufficiently concrete and specific, ${ }^{10}$ and possess the ability to transfer "precise information". ${ }^{11}$ According to the CJEU, the concept of a sign should notably be understood against the background of the essential function of trade marks "to guarantee the identity of the origin of the marked product or service to the consumer or end user by enabling him, without any possibility of confusion, to distinguish that product or service from others which have another origin". 12 From that, it follows that the requirement of a sign boils down to determining whether something has the abstract ability to distinguish. ${ }^{13}$ In other words, given subject matter will constitute a sign only if it is capable of having

\footnotetext{
5 GC 12 June 2007, T-339/05, MacLean-Fogg, EU:T:2007:172, para. 57; GC 13 September 2016, T-408/ 15, Globo Comunicação, EU:T:2016:468, para. 63.

6 CJEU 27 November 2003, C-283/01, Shield Mark, EU:C:2003:641, paras. 39-40.

7 EUTM Regulation, Art. 4; TM Directive, Art. 3; CJEU 12 December 2002, C-273/00, Sieckmann, EU:C:2002:748, para. 39; CJEU 6 May 2003, C-104/01, Libertel, EU:C:2003:244, para. 23; CJEU 24 June 2004, C-49/02, Heidelberger Bauchemie, EU:C:2004:384, para. 22; CJEU 10 July 2014, C-421/13, Apple, EU:C:2014:2070, para. 17.

8 CJEU 24 June 2004, C-49/02, Heidelberger Bauchemie, EU:C:2004:384, para. 23; Larrieu and Astic (2004), para. 2.

9 Schneider (2018), para. 6.

10 GC 23 September 2020, T-796/16, CEDC Int., EU:T:2020:439, para. 130.

11 Janssens (2019), p. 46.

12 CJEU 12 December 2002, C-273/00, Sieckmann, EU:C:2002:748, para. 35; CJEU 12 February 2004, C-218/01, Henkel, EU:C:2004:88, para. 30.

13 Hasselblatt (2018), paras. 43-46; Larrieu and Astic (2004), para. 2; Schneider (2018), para. 7.
} 
distinctive character, at least theoretically and without regard to the concrete goods or services for which trade mark protection is sought. ${ }^{14}$ In particular, this condition will not be fulfilled if consumers do not recognise given subject matter as a sign, but rather as a mere property or feature of a product. ${ }^{15}$ Whether a sign is distinctive in relation to the specific goods or services for which protection is sought is a distinct question assessed at a subsequent stage. ${ }^{16}$

\subsubsection{International Law}

There are no WIPO treaties that provide compulsory limits on the types of signs eligible for trade mark protection in the jurisdiction of the signatory parties. By contrast, TRIPS does provide for a non-exhaustive list of signs that "shall be capable of constituting a trademark" ${ }^{17}$ However, that list does not refer to any nonvisual signs. Moreover, TRIPS clarifies that treaty members "may require, as a condition of registration, that signs be visually perceptible". ${ }^{18}$ In conclusion, international trade mark law leaves states to include or exclude non-visual signs, such as the ones investigated, at their discretion.

Although the Paris Convention ${ }^{19}$ leaves trade marks undefined and does not allow any conclusions to be drawn directly about the types of signs to be protected by national trade mark legislation, it has been argued in the literature that Art. $6^{\text {quinquies }}$ of that Convention indirectly requires Paris Union member states to grant trade mark protection to certain non-traditional trade marks in limited instances after all. ${ }^{20}$ Pursuant to that Article, also referred to as the Telle quelle ("as is") clause, "[e]very trademark duly registered in the country of origin shall be accepted for filing and protected as is in the other countries of the Union", subject to a closed list of reservations. ${ }^{21}$ Meant to bring legal certainty to holders of a foreign trade mark who want to register the same mark in another state when some trade mark laws prohibited the registration of surnames or single letters and the like, the Article stipulates that such marks may be neither denied registration nor invalidated, except when they infringe third-party rights, when they are devoid of any distinctive character, or when they are contrary to morality or public order or, in particular, deceptive.

\footnotetext{
14 See CJEU 10 July 2014, C-421/13, Apple, EU:C:2014:2070, para. 21; Larrieu and Astic (2004), para. 2 .

15 CJEU 25 January 2007, C-321/03, Dyson, EU:C:2007:51, paras. 32 and 35-40; GC 23 September 2020, T-796/16, CEDC Int., EU:T:2020:439, paras. 127-131.

16 Ch. 2.3 .

17 Agreement on Trade-Related Aspects of Intellectual Property Rights, Annex 1C to the Marrakesh Agreement Establishing the World Trade Organization (1994) 1867 UN Treaty Series 69 ("TRIPS Agreement"), Art. 15(1).

18 TRIPS Agreement, Art. 15(1).

19 Convention de Paris pour la protection de la propriété industrielle (1883, Stockholm version 1967) 828 UN Treaty Series 305 ("Paris Convention").

20 Zhan (2017), p. 131.

${ }^{21}$ Paris Convention, Art. $6^{\text {quinquies }}(\mathrm{A})(1)$.
} 
Despite its potential, the Telle quelle clause seems not to have been used (yet) to claim trade mark protection for non-traditional types of signs that are currently not protectable in the EU but have been registered in a non-member state, like smells. It is questionable whether such an application would be successful, though. The Article was drafted with only traditional, visual, trade marks in mind, so trade mark offices and courts might be reluctant to register subject matter that they consider not to be a sign or not capable of being represented on the register. Moreover, it is hard to see how a non-visual sign could be entered in a register that is not adapted to host that type of sign. Finally, it has been argued that applications of this kind would probably be denied by reference to a lack of distinctiveness or to the finding that allowing registration would simply run counter to national public order. ${ }^{22}$

\subsubsection{Olfactory, Gustatory and Tactile Marks}

The CJEU has not directly considered whether smells, tastes or feel can constitute protectable signs under European harmonised trade mark law. Yet the Court did find that the lawmaker had not excluded any particular types of signs from trade mark protection ex ante, and that a sign did not need to be visual to qualify for trade mark protection. ${ }^{23}$ In keeping with the German Federal Supreme Court's case-law, ${ }^{24}$ it held that it sufficed if subject matter could be perceived by consumers through any of the five human senses. ${ }^{25}$ Taking into account the essential function of trade marks to indicate origin, this condition thus essentially amounts to determining whether a smell, taste or feel is theoretically suitable for indicating origin.

In this respect, it is hardly contested ${ }^{26}$ that smells possess the abstract ability to fulfil the essential function of trade marks to identify origin. ${ }^{27}$ According to Advocate General Colomer, “... studies of the perception of odours have shown that the olfactory memory is probably the best one that humans possess". ${ }^{28}$ In the same vein, the General Court affirms that the human memory in relation to smell is highly reliable and could therefore be a good indication of origin. ${ }^{29}$ The same seems true for tastes: it is perfectly conceivable that one can indicate the origin of a certain product on the basis of a taste.

Despite these arguments, it should not be ignored that, in a case on the ability to protect tastes by copyright, the CJEU Grand Chamber remarked that

\footnotetext{
22 Ribeiro da Cunha and Randakeviciute-Alpman (2020), p. 392; Wee Loon (2018), p. 164.

23 CJEU 12 December 2002, C-273/00, Sieckmann, EU:C:2002:748, para. 45; CJEU 27 November 2003, C-283/01, Shield Mark, EU:C:2003:641, para. 35.

${ }^{24}$ German Federal Supreme Court 5 October 2006, I ZB 73/05, 169 BGHZ 175, para. 12 - III.2.

25 CJEU 25 January 2007, C-321/03, Dyson, EU:C:2007:51, para. 30; Max Planck Institute for Intellectual Property and Competition Law (2011) Study on the Overall Functioning of the European Trade Mark System. Para. 2.10. https://op.europa.eu/s/pBi7. Accessed 9 September 2021.

26 See, however, Elias (1992), pp. 479-483.

27 Fezer (2009), MarkenG § 3, paras. 606-607; Hasselblatt (2018), para. 322.

28 AG Ruiz-Jarabo Colomer, opinion on CJEU 12 December 2002, C-273/00, Sieckmann, EU:C:2001:594, para. 29.

29 GC 27 October 2005, T-305/04, Eden, EU:T:2005:380, para. 25.
} 
the taste of a food product will be identified essentially on the basis of taste sensations and experiences, which are subjective and variable since they depend, inter alia, on factors particular to the person tasting the product concerned, such as age, food preferences and consumption habits, as well as on the environment or context in which the product is consumed. ${ }^{30}$

This reasoning makes it uncertain whether the CJEU will ever be convinced that a taste can constitute a sufficiently specific expression to be a sign. Nonetheless, the reasoning could be countered by the argument that every sign (as well as every work of authorship) depends on the subjective and variable sensations and experiences of the human being who is interpreting it. Indeed, is it not rather the lack of refined vocabulary about non-visual and non-audible subject matter that makes it difficult to objectively communicate about tastes?

In relation to tactile marks, it should not be ignored that the German judiciary has held that it cannot be excluded from the outset that a touch or feeling might constitute a sign. ${ }^{31}$ Applying the sign/mere property dichotomy outlined above, the Federal Supreme Court asserted that, at least as a theoretical exercise, the touch of a product should be able to be abstracted from the product itself in order to qualify as a sign. ${ }^{32}$ Although only CJEU case-law may bring certainty in this respect, it seems provisionally safe to conclude that neither olfactory marks, nor gustatory marks, nor tactile marks are per se excluded from trade mark protection de lege lata.

\subsection{Representability on the Register}

Signs can only be protected by a trade mark if they are "capable of being represented on the [national or EU Trade Mark register] [...] in a manner which enables the competent authorities and the public to determine the clear and precise subject matter of the protection afforded to its proprietor". ${ }^{33}$ Indeed, unambiguous representation is important, because a sign's representation in the register defines the scope of the mark itself, and therefore determines the scope of the protection afforded to the trade mark owner. The representation requirement should therefore guarantee that trade mark offices and courts, as well as competitors, are able to see clearly what is registered or applied for. ${ }^{34}$ Indeed, a major objective of the

\footnotetext{
${ }^{30}$ CJEU 13 November 2018, C-310/17, Levola Hengelo, EU:C:2018:899, para. 42; see likewise CJEU 12 September 2019, C-683/17, Cofemel, EU:C:2019:721, para. 34.

31 German Federal Supreme Court 5 October 2006, I ZB 73/05, 169 BGHZ 175, para. 12 - III.2; German Federal PatC 23 March 2007, 26 W (pat) 3/05, 2008 GRUR 348, para. II.1.

32 German Federal Supreme Court 5 October 2006, I ZB 73/05, 169 BGHZ 175, para. 12 - III.2.

33 EUTM Regulation, Art. 4(b); TM Directive, Art. 3(b).

34 CJEU 12 December 2002, C-273/00, Sieckmann, EU:C:2002:748, paras. 47-55; CJEU 6 May 2003, C-104/01, Libertel, EU:C:2003:244, paras. 27-29; CJEU 24 June 2004, C-49/02, Heidelberger Bauchemie, EU:C:2004:384, paras. 28-30; cf. in relation to copyight, CJEU 13 November 2018, C-310/17, Levola Hengelo, EU:C:2018:899, paras. 40-41; CJEU 12 September 2019, C-683/17, Cofemel, EU:C:2019:721, paras. 32-33; CJEU 11 June 2020, C-833/18, SI and Brompton Bicycle v. Chedech/ Get2Get, EU:C:2020:461, para. 25.
} 
representation criterion is "to prevent the abuse of trade mark law in order to obtain an unfair competitive advantage". 35

Before 2017, "graphical" representation was required. The CJEU has been attributing a modern interpretation to that requirement since the 2002 Sieckmann judgment, though. Pursuant to established case-law, a sign should indeed not necessarily be depicted by graphical means. Instead, it suffices that it is capable of being represented in a way that is "clear, precise, self-contained, easily accessible, intelligible, durable and objective", regardless of whether the sign itself can be perceived visually. ${ }^{36}$ On the occasion of the 2015 Trade Mark Reform Package, these criteria were codified in contemporary trade mark legislation ${ }^{37}$ with a view to ensuring continuity. ${ }^{38}$ It was added that a sign "should be permitted to be represented in any appropriate form using generally available technology". 39 As a result, registrations have increasingly been accepted in new digital formats. ${ }^{40}$

In the recent past, CJEU case-law was the only prime source to determine how the (then graphical) representability criterion could be met for certain nontraditional marks. For single-colour marks, it held for instance that "the designation of a colour using an internationally recognised identification code may be considered to constitute a graphic representation", potentially combined with samples and/or descriptions. ${ }^{41}$ For colour combinations, the Court found that "a graphic representation consisting of two or more colours, designated in the abstract and without contours, must be systematically arranged by associating the colours concerned in a predetermined and uniform way" to meet the requirement. Merely juxtaposing two or more colours or referring to their combination "in every conceivable form" was found to be not sufficiently precise and uniform. ${ }^{42}$

Today, the EU Trade Mark Implementing Regulation and EUIPN policy documents lay down detailed rules on how to file different types of trade marks ${ }^{43}$ in conformity with the Sieckmann criteria. Many of these rules coincide with those laid

\footnotetext{
35 CJEU 24 June 2004, C-49/02, Heidelberger Bauchemie, EU:C:2004:384, para. 24.

36 CJEU 12 December 2002, C-273/00, Sieckmann, EU:C:2002:748, para. 55; CJEU 6 May 2003, C-104/ 01, Libertel, EU:C:2003:244, paras. 28-29; CJEU 24 June 2004, C-49/02, Heidelberger Bauchemie, EU:C:2004:384, paras. 28-30.

37 EUTM Regulation, Recital 10; TM Directive, Recital 13; EUTM Implementing Regulation, Art. 3(1).

38 Fields and Muller (2017), p. 243; Schneider (2018), para. 16; Schumacher (1 July 2021), para. 494.

39 EUTM Regulation, Recital 10; TM Directive, Recital 13; italics added.

40 EUIPN (April 2021) CP11, p. 20

41 CJEU 6 May 2003, C-104/01, Libertel, EU:C:2003:244, paras. 37-38; CJEU 24 June 2004, C-49/02, Heidelberger Bauchemie, EU:C:2004:384, para. 36.

42 CJEU 24 June 2004, C-49/02, Heidelberger Bauchemie, EU:C:2004:384, paras. 33-34.

43 EUTM Implementing Regulation, Art. 3(3); EUIPN (2018/19) Common Communication on the Representation of New Types of Trade Marks. CC8, pp. 4-10. https://euipo.europa.eu/tunnel-web/secure/ webdav/guest/document_library/contentPdfs/about_euipo/who_we_are/common_communication/ common_communication_8/common_communication8_en.pdf. Accessed 9 September 2021; EUIPN (April 2021) CP11, pp. 20-21.
} 
down in the Regulations ${ }^{44}$ complementing the Singapore Treaty, ${ }^{45}$ a 2006 WIPO treaty that provides for a minimum amount of harmonisation for trade mark registrations, though without imposing obligations on its parties to recognise nontraditional marks. ${ }^{46}$ Unlike sound and motion marks, trade marks in smells, tastes and feel are unfortunately not covered by the EU Trade Mark Implementing Regulation and the EUIPN Common Practice document. In order to determine to what extent these three signs meet the representability requirement, one can therefore only test them against the general requirements as laid down in legislation and interpreted by the judiciary.

\subsubsection{Olfactory Marks}

In the era predating the Sieckmann doctrine, some olfactory marks had already been successfully applied for. In 1996, UK trade marks were granted for a sign described as "the strong smell of bitter beer applied to flights for darts" and for "a floral fragrance/smell reminiscent of roses as applied to tyres". ${ }^{47}$ Similarly, in 1999, the OHIM Board of Appeal found that a verbal description mentioning "the smell of fresh cut grass" was sufficiently distinct and appropriate to comply with the requirement of (graphical) representation, and granted the Community trade mark for tennis balls. ${ }^{48}$

What was possible in the 90 s would no longer be so in the new millennium. ${ }^{49}$ In the 2002 Sieckmann judgment, the CJEU explained that representability required a clear, precise, self-contained, easily accessible, intelligible, durable, and objective representation of a sign, and applied that doctrine to a variety of potential modes for representing smells. It considered that chemical formulas were not suitable for representing a smell because few people would recognise an odour on the basis of a formula, and because a formula represents a smell-producing substance rather than a smell itself. ${ }^{50}$ In a 2005 judgment, the General Court generalised that finding, arguing that submitting an image of a smell-producing substance as a graphical representation did not suffice to identify the claimed smell itself, even if the representation was combined with a verbal description. ${ }^{51}$ In that case, it refused an

\footnotetext{
44 Regulations under the Singapore Treaty on the Law of Trademarks (as in force on 1 November 2011), Rule 3.

45 Singapore Treaty on the Law of Trademarks (2006) 2633 UN Treaty Series 1-3.

${ }^{46}$ Resolution by the Diplomatic Conference supplementary to the Singapore Treaty on the Law of Trademarks, para. 3(i).

47 UK TM application 31 October 1994, registered 3 May 1996, UK00002000234, Unicorn Products (ongoing); UK TM application 31 October 1994, registered 9 April 1996, UK00002001416, Goodyear Dunlop Tyres $U K$ (expired).

48 OHIM BoA 11 February 1999, R 156/1998-2, Senta Aromatic Marketing, paras. 14-15; see CTM application 11 December 1996, 000428870, registered 11 October 2000, Senta Aromatic Marketing (expired 11 December 2006).

49 Fezer (2009), MarkenG $\S 3$, para. 611.

50 CJEU 12 December 2002, C-273/00, Sieckmann, EU:C:2002:748, para. 69; GC 27 October 2005, T-305/04, Eden, EU:T:2005:380, para. 39.

51 GC 27 October 2005, T-305/04, Eden, EU:T:2005:380, paras. 40-41.
} 
application containing the image of a strawberry and the wording "smell of ripe strawberries" in the graphical representation field, essentially because not all (varieties of) strawberries possess one unique smell, making the representation too subjective. $^{52}$

In Sieckmann, the filing of samples or specimens was also explicitly ruled out by the CJEU. ${ }^{53}$ As specimens of smells, or any specimens for that matter, are rarely stable and durable, they are never accepted in EU trade mark practice. ${ }^{54}$ This is different in the US, where olfactory marks - although very limited in number ${ }^{55}$ have been registered on the basis of applications that included an olfactory sample and a detailed description of the trade mark protection applied for. ${ }^{56}$ According to the CJEU, however, entries in the description field cannot describe a smell sufficiently to meet the representability requirement. ${ }^{57}$ In this respect, it is relevant that there are no internationally accepted classifications or code systems like the ISO colour codes for colour marks or music notation for sound marks. ${ }^{58}$ More generally, though, it is established EU case-law that descriptions are, in principle, irrelevant when assessing the validity and the scope of trade marks, and that they cannot extend or alter the scope of a trade mark application as defined by the disclosed representation. ${ }^{59}$ Finally, the CJEU has upheld that combinations of any of the aforementioned modes of representation would not fulfil the representability requirement either. ${ }^{60}$

Referring to the criteria established in the Sieckmann judgment and the discard of all the modes of representation therein, the General Court left one opening for the representability of olfactory marks in a judgment predating the 2015 trade mark reforms by a decade. According to that Court, it would be possible, at least in theory, to represent a smell verbally with sufficient precision if the chosen wording were not overly subjective, which has to be assessed case by case. ${ }^{61}$ However, today, that door seems to have closed as well. Although the wording of the representability requirement was altered mainly to consolidate the Sieckmann

\footnotetext{
52 Id., paras. 31-33.

53 CJEU 12 December 2002, C-273/00, Sieckmann, EU:C:2002:748, para. 71; cf. CJEU 6 May 2003, C-104/01, Libertel, EU:C:2003:244, para. 32.

54 See EUTM Implementing Regulation, Art. 3(9).

55 See Ribeiro da Cunha and Randakeviciute-Alpman (2020), para. 18 and fns. 74-75.

56 E.g. USTM application 25 August 1995, 74720993, registered 26 June 2001, 2463044, Power Plus Lubricants; USTM application 29 April 2014, 86265443, registered 16 June 2015, 4754435, Grendene; USTM application 14 February 2017, 87335817, registered 15 May 2018, 5467089, Hasbro; $c f$. USPTO (2021) Trademark Manual of Examining Procedure. Para. 904.03(m). https://www.uspto.gov/trademarks/ guides-and-manuals/tmep-archives. Accessed 9 September 2021.

57 CJEU 12 December 2002, C-273/00, Sieckmann, EU:C:2002:748, para. 70.

58 GC 27 October 2005, T-305/04, Eden, EU:T:2005:380, para. 34; Elias (1992), p. 491.

59 EUTM Implementing Regulation, Art. 3(2), second phrase; CJEU 29 July 2019, C-124/18 P, Red Bull, EU:C:2019:641, para. 37; GC 31 May 2006, T-15/05, De Waele, EU:T:2006:142, para. 36; GC 12 September 2007, T-358/04, Neumann, EU:T:2007:263, para. 53; GC 23 September 2020, T-796/16, CEDC Int., EU:T:2020:439, paras. 108-109.

60 CJEU 12 December 2002, C-273/00, Sieckmann, EU:C:2002:748, para. 72; $f$. GC 27 October 2005, T-305/04, Eden, EU:T:2005:380, paras. 43-46.

61 See GC 27 October 2005, T-305/04, Eden, EU:T:2005:380, paras. 27-33.
} 
doctrine into EU legislation, the EUIPO and some eminent scholars take the rather absolute view that the subject matter of protection of olfactory marks cannot be determined with sufficient clarity and precision with generally available technology for the time being. ${ }^{62}$ Likewise, the EUIPN has omitted these marks from its policy documents on "new types of marks". ${ }^{63}$ However, it cannot be ruled out that future technologies will enable new modes of reproduction for smells, sufficiently finetuned to meet the representability criterion. ${ }^{64}$

The conclusions on the inability to represent smells in the trade mark register have been criticised in literature. Fezer, for one, argues that, in fact, it is technically possible, or at least conceivable, to represent smells graphically. He refers, inter alia, to gas-chromatographic analyses, smell "printers" and microcapsules filled with fragrances that are released on the basis of triggers. ${ }^{65}$ He rightly adds ${ }^{66}$ that the economic impact or (societal) need for the protection of olfactory marks should be considered irrelevant, at least for the interpretation of the representability criterion. From that, he deduces that trade mark registers should be adapted so as to incorporate smells instead of the other way round. ${ }^{67}$ Nonetheless, it is questionable whether the suggested modes of representation make use of "generally available technology" in accordance with the considerations of the 2015 trade mark legislator: ${ }^{68}$ are these technologies sufficiently established, affordable and reliable (yet)? These questions are further elaborated on below. In any case, it is clear that current practice in trade mark offices is not to allow olfactory marks for want of a clear, precise - and objective - mode of representation.

\subsubsection{Gustatory Marks}

If smells cannot be protected by trade marks owing to lack of representability, then surely neither can tastes; that essentially encapsulates the majority view on gustatory marks. As such, in 2003, both the OHIM Board of Appeal and the Paris Court of Appeal argued that a representation consisting of the statement "taste of artificial strawberry flavour" was not sufficiently stable, subjective, and precise to satisfy the Sieckmann criteria. ${ }^{69}$ Fifteen years later, in a judgment about the (im)possibility of protecting tastes by copyright, the CJEU Grand Chamber confirmed that it was still "not possible in the current state of scientific development to achieve by technical means a precise and objective identification of the taste of a

\footnotetext{
${ }^{62}$ EUIPO (2021) [Trade Mark] Guidelines for Examination. P. 235. https://euipo.europa.eu/ohimportal/ en/guidelines. Accessed 9 September 2021; Durrande and Canlorbe (22 June 2021), para. 8; Schneider (2018), para. 46.

63 See e.g. EUIPN (2018/19) CC8, pp. 4-5.

64 Schneider (2018), para. 48; $c f$. Ribeiro da Cunha and Randakeviciute-Alpman (2020), p. 392.

65 Fezer (2009), MarkenG § 3, paras. 476 and 608.

66 See, however, Sect. 4.

67 Fezer (2009), MarkenG § 3, para. 608.

68 EUTM Regulation, Recital 10; TM Directive, Recital 13.

69 Paris CA 3 October 2003, 2004 Dalloz 2433; OHIM BoA 4 August 2003, R 120/2001-2, Eli Lilly, para. 12.
} 
food product which enables it to be distinguished from the taste of other products of the same kind". ${ }^{70}$ Indeed, the lack of international standards, widely accepted industry codes and even common vocabulary to describe tastes in detail has made it impossible to distinguish tastes on the register in a durable manner "using generally available technology", and it is quite uncertain whether such technology will be available soon, or ever. ${ }^{71}$

\subsubsection{Tactile Marks}

The number of decisions on tactile trade marks is very limited. In 2015, the OHIM Board of Appeal explained that the sub-requirement of a "self-contained" representation "means that third parties viewing the [EUTM] Bulletin, should on their own and without additional technical means, be able to understand what [the] claimed "particular sensation to the touch' [...] is". In the case in question, the trade mark application contained a photo in the graphic representation field and a description stating that the trade mark applied for consisted in "the tactile feeling constituted by the imprinted embossed pattern on the smooth bottle surface", with a disclaimer regarding the visual representation, "which is attached only for information purposes". The Board refused to register this trade mark, arguing that the visual representation was not a clear and self-contained representation of the mark itself; it considered that it was "impossible to deduce from the image as filed to identify with certainty the claimed "tactile feeling,", 72

In a case about an application for a tactile mark for automotive parts, the German Federal Supreme Court proved to be less strict regarding the requirement of representation. It clarified that trade mark law did not necessarily require an applicant to be able to represent "the feeling itself", that is to say what is felt by third parties. Indeed, the Court found it sufficient for the (graphical) representation to represent the claimed sign only in an indirect manner, provided that the Sieckmann criteria were met. In summary, images, words, or a combination thereof should describe the haptic characteristics with sufficient precision to allow the public to know exactly what is being felt. ${ }^{73}$

Despite that liberal approach, there have been no successful examples of tactile marks in Germany to date. As such, the German Federal Patent Court did not accept an application for "the raw feeling of fine sand paper" applied to beer bottles, due to the lack of a sufficiently objective description. It came to that conclusion because it considered "raw" (rauh) to be a qualification that necessarily touched upon the subjective findings of the receiver, and because it found "fine sand paper" terminologically so broad that it could cover a whole variety of grain gradations. ${ }^{74}$ Even a reference to a DIN ISO norm (6344) for abrasives with certain macro-grain

\footnotetext{
70 CJEU 13 November 2018, C-310/17, Levola Hengelo, EU:C:2018:899, para. 43.

71 Ribeiro da Cunha and Randakeviciute-Alpman (2020), p. 392.

72 OHIM BoA 27 May 2015, R 2588/2014-2, The Procter \& Gamble Company, paras. 20-21.

73 German Federal Supreme Court 5 October 2006, I ZB 73/05, 169 BGHZ 175, paras. 15-17 - III.4-5.a; Fezer (2009), MarkenG § 3, paras. 487 and 493; Schoene (2006); Schrader (2007), p. 152.

74 German Federal PatC 23 March 2007, 26 W (pat) 3/05, 2008 GRUR 348, para. II.2.
} 
sizes ( $\mathrm{P} 12$ to $\mathrm{P} 220$ ) in the description of the application was considered by the Patent Court as not allowing a sufficiently clear individualisation.

So far, no EU case-law has been formed on the representability of tactile marks. Moreover, it remains to be seen whether the updated representation criterion will change anything in the near future. ${ }^{75}$ For now, the EUIPO Guidelines and the EUIPN favour applying the same reasoning as for smells to signs consisting of a touch or a feeling, though. There is no generally available technology that allows a tactile feeling to be deduced; such signs are therefore considered absolutely incapable of being represented on the register in accordance with the Sieckmann criteria. $^{76}$ Given the arguments developed in German case-law and doctrine, one could wonder whether that stance is not overly radical.

\subsubsection{Remarks}

The analysis shows that the three non-traditional signs under examination currently all founder on the requirement of being capable of representation in the register with sufficient clarity and precision. ${ }^{77}$ This holds true, at least, according to the majority view and EU trade mark practice. The result thereof is that - unlike sound marks ${ }^{78}$ smell, taste, and touch marks are currently absolutely excluded from protection as non-visual trade marks, for the requirement of representability is an insurmountable hurdle that cannot be overcome by acquired distinctiveness. ${ }^{79}$

In relation to olfactory, gustatory, and tactile marks, an oft-heard argument is that the reason they are not represented is because contemporary technical means do not allow these three sensory perceptions to be described without any element of subjectivity. ${ }^{80}$ Nonetheless, it should be noted that musical notation is equally subjective in nature. ${ }^{81}$ A score is always open to interpretation; there are scholars who devote their entire lives to interpreting sheet music. Yet this does not seem to have caused insurmountable issues for the registration of sound marks. ${ }^{82}$ More generally speaking, the perception of every sign is always accompanied by subjective elements, regardless of its type ${ }^{83}$ Hence, does the core issue not lie, on the one hand, in the fact that we (think that we) lack a fully-fledged vocabulary to express ourselves with sufficient precision about what we smell, taste, and feel and, on the other hand, in the fact that current digital information technology does not allow that gap to be filled?

\footnotetext{
75 Schumacher (1 July 2021), para. 503.

76 EUIPO (2021), p. 235; cf. EUIPN (2018/19) CC8, pp. 4-5.

77 Hasselblatt (2018), para. 48.

78 See EUTM Implementing Regulation, Art. 3(3)(g); CJEU 27 November 2003, C-283/01, Shield Mark, EU:C:2003:641,

79 Fezer (2009), MarkenG § 3, para. 609.

${ }^{80}$ See e.g. GC 27 October 2005, T-305/04, Eden, EU:T:2005:380, para. 33; Pauwels (2016), pp. 1-3.

${ }^{81}$ Schneider (2018), para. 47.

82 See CJEU 27 November 2003, C-283/01, Shield Mark, EU:C:2003:641, para. 62; GC 13 September 2016, T-408/15, Globo Comunicação, EU:T:2016:468, para. 34; cf. EUIPO (2021), p. 230.

${ }^{83}$ Fezer (2009), MarkenG $\S 3$, para. 486; Schneider (2018), para. 47.
} 
As far as non-visual trade marks are concerned, the representability requirement essentially boils down to the level of detail and transparency that can be required from a trade mark representation. If one requires users consulting the digital register to be able to truly smell, taste, or feel the subject matter applied for with their own noses, mouths, and hands, then most probably these three types of trade mark will not be accepted in the next decade. Today, most economic actors possess a computer with a monitor and a sound device. By contrast, a universal smell, taste or feel "printer" does not currently exist; the limited aroma-printing devices that do exist are not generally available on the market at a reasonable price, and 3D printers are still expensive and print only textures that can be obtained from the material that is fed into them. Alternatively, one could argue that the representability criterion should at least be deemed met for those smells and touches that can be reproduced by these devices. In this respect, it is equally arguable that it should suffice for the trade mark office involved to have a device that can "print" the subject matter when a digital file with printing instructions (like STL files for 3D printers) is supplied. As to the argument that members of the public could consult the register only with the active intervention of the trademark office, it must not be overlooked that, even less than a few decades ago, in the pre-internet era, consulting a trade mark register always necessitated the office's active intervention: transparency does not necessarily coincide with universal availability.

In a less strict approach towards the representation requirement, applications could alternatively be considered sufficiently capable of representation if the smell, taste, or touch were expressed by words, images, or a combination thereof. In fact, this has been the approach mostly followed to date in the (scarce) case-law. ${ }^{84}$ Yet it seems to have been rejected by the EUIPO from the outset. ${ }^{85}$ When this approach is taken, the crux lies in determining how precise and detailed verbal descriptions and images need to be in order to fulfil the Sieckmann criteria.

To date, the standard appears to be insurmountably high: there are no postSieckmann cases of accepted olfactory, gustatory, or tactile marks. Nonetheless, it could be asked what additional precision can be expected from descriptions like "the strong smell of bitter beer applied to flights for darts", 86 or references to specific ISO norms to identify a specific type of sand paper. ${ }^{87}$ Are these descriptions truly open to many divergent interpretations? Even a zythologist would probably not be able to distinguish in detail between various bitter beer types on the basis of their smell applied to darts gear. Moreover, it is quite remarkable that the German Federal Patent Court considered ISO norms to be insufficiently clear to identify a tactile sign, as it is difficult to see what can be clearer, more precise, and more objective, using generally available technology, than a reference to ISO norms. ${ }^{88}$

\footnotetext{
84 GC 27 October 2005, T-305/04, Eden, EU:T:2005:380, paras. 27-33; German Federal Supreme Court 5 October 2006, I ZB 73/05, 169 BGHZ 175, paras. 15-17 - III.4-5.a.

85 EUIPO (2021), p. 235.

${ }^{86}$ UK TM application 31 October 1994, registered 3 May 1996, UK00002000234, Unicorn Products (ongoing).

87 German Federal PatC 23 March 2007, 26 W (pat) 3/05, 2008 GRUR 348.

88 Fezer (2009), MarkenG § 3, para. 625.
} 
To a certain extent, the choice of allowing the representability requirement a very narrow interpretation seems to be a convenient gateway to set a threshold so insurmountably high that olfactory, gustatory, and tactile marks will, in fact, never be able to be described in words and depicted graphically with sufficient precision. Hence, one may wonder whether the strict interpretation of this requirement is not essentially driven by other concerns, like a sensed need to keep certain subject matter out of the trade mark field. Whether that need is justified and where its place is in the discourse of non-traditional trade marks is further elaborated on below. ${ }^{89}$ At this stage, however, it should not be overlooked that the trade mark system does not give trade mark offices or courts discretion to grant or deny trade mark protection. Instead, they must act in compliance with legislative norms, as interpreted in EU case-law, ${ }^{90}$ and applicants are entitled to have a trade mark registered as soon as the legislative conditions are met. ${ }^{91}$ Against that background, it is questionable whether it is justified for the representability standard to in fact limit the signs that can be protected to those that can be digitally represented - especially where tactile marks are concerned.

\subsection{Distinctiveness}

Given that a trade mark's essential function is to guarantee the identity of the commercial origin of the marked product or service to the consumer, ${ }^{92}$ a sign that can be represented must also have distinctive character in order for it to constitute a valid trade mark. ${ }^{93}$ Testing such distinctive character requires a case-by-case analysis that takes into account two particular factors: the goods or services in respect of which trade mark protection has been applied for, on the one hand, and the perception of the trade mark by the average consumers of those goods or services, on the other. ${ }^{94}$ Moreover, the distinctiveness of a mark is a characteristic

\footnotetext{
89 See Sect. 4.

90 CJEU 15 September 2005, C-37/03 P, BioID, EU:C:2005:547, para. 47; CJEU 12 January 2006, C-173/04 P, Deutsche SiSi-Werke, EU:C:2006:20, para. 48; CJEU 16 July 2009, C-202/08 P and C-208/ 08 P, American Clothing Associates, EU:C:2009:477, para. 57; CJEU 19 January 2012, C-53/11 P, Nike, EU:C:2012:27, para. 57; CJEU 6 September 2018, C-488/16 P, Freistaat Bayern, EU:C:2018:673, para. 72; GC 22 June 2005, T-19/04, Metso Paper Automation, EU:T:2005:247, para. 39; GC 13 September 2016, T-408/15, Globo Comunicação, EU:T:2016:468, para. 71.

91 Fezer (2009), MarkenG § 3, para. 608.

92 CJEU 18 June 2002, C-299/99, Philips, EU:C:2002:377, para. 35; CJEU 8 April 2003, C-53/01 to C-55/01, Linde, EU:C:2003:206, para. 40; Schumacher (1 July 2021); Voßberg (2021).

93 EUTM Regulation, Art. 4(a); TM Directive, Art. 3(a).

94 CJEU 18 June 2002, C-299/99, Philips, EU:C:2002:377, para. 63; CJEU 8 April 2003, C-53/01 to C-55/01, Linde, EU:C:2003:206, para. 41; CJEU 6 May 2003, C-104/01, Libertel, EU:C:2003:244, para. 75; CJEU 12 February 2004, C-218/01, Henkel, EU:C:2004:88, para. 50; CJEU 29 April 2004, C-456/01, Henkel, EU:C:2004:258, para. 35; CJEU 28 June 2004, C-445/02 P, Glaverbel, EU:C:2004:393, para. 20; CJEU 16 September 2004, C-404/02, Nichols, EU:C:2004:538, para. 23; CJEU 7 October 2004, C-136/02 P, Mag Instrument, EU:C:2004:592, para. 19; CJEU 12 January 2006, C-173/04 P, Deutsche SiSi-Werke, EU:C:2006:20, para. 25; CJEU 22 June 2006, C-25/05 P, Storck, EU:C:2006:422, para. 25; CJEU 20 October 2011, C-344/10 P and C-345/10 P, Freixenet, EU:C:2011:680, para. 43; CJEU 24 May 2012, C-98/11 P, Lindt, EU:C:2012:307, para. 41; CJEU 10 July 2014, C-421/13, Apple, EU:C:2014:2070, para. 22; CJEU 12 December 2019, C-783/18 P, Wajos, EU:C:2019:1073, para. 23.
} 
that can vary over time. Unlike with representability, ${ }^{95}$ a sign that was formerly not distinctive can indeed acquire distinctive character through use, and a sign that was formerly distinctive can become descriptive as a result of dilution. ${ }^{96}$

All signs, whether visual or non-visual, are subject to the same principles for the assessment of distinctiveness, ${ }^{97}$ regardless of whether the sign concerned can or cannot be attached to the goods or services, be used together with them, or be incorporated in their packaging, and so on. ${ }^{98}$ However, this does not diminish the fact that assessing the distinctive character of a non-visual mark may not be as straightforward as for more traditional marks. Despite the principle that marks ought not to be treated differently according to the type of sign applied for, the CJEU indeed consistently rules that the perception of consumers of the relevant goods or services is not necessarily the same for each and every type of mark. ${ }^{99}$ Because of this reasoning, certain non-traditional marks will de facto need to meet a higher threshold in order to qualify for protection. This is true, in particular, for marks that coincide with the appearance of the product itself, like colour marks and shape marks for packaging. ${ }^{100}$ Without prejudice to the need for a case-by-case analysis, the same may apply to the non-visual marks within the scope of this article. In the remainder of this section, the ability of smells, tastes and feels to indicate commercial origin is therefore analysed in detail.

\subsubsection{Olfactory Marks}

Although it has been argued that smells would make strong trade marks thanks to our well-developed abilities as humans to recognise and identify odours, the majority view seems to be that olfactory signs cannot be registered owing to lack of objective representability on the register to date. ${ }^{101}$ As a result, the assessment of the distinctive character of smells is currently a rather theoretical matter in Europe.

\footnotetext{
95 See Sect. 2.2.4.

96 Cf. EUTM Regulation, Art. 7(1)(d) and 7(3); TM Directive, Art. 4(1)(d) and 4(4).

97 CJEU 22 June 1999, C-342/97, Lloyd, EU:C:1999:323, paras. 22-27; CJEU 12 February 2004, C-218/ 01, Henkel, EU:C:2004:88, para. 31; CJEU 29 April 2004, C-456/01, Henkel, EU:C:2004:258, para. 37; CJEU 24 June 2004, C-49/02, Heidelberger Bauchemie, EU:C:2004:384, para. 41; CJEU 10 July 2014, C-421/13, Apple, EU:C:2014:2070, para. 23.

98 EUIPN (April 2021) CP11, p. 22.

99 CJEU 22 June 1999, C-342/97, Lloyd, EU:C:1999:323, para. 26; CJEU 28 June 2004, C-445/02 P, Glaverbel, EU:C:2004:393, paras. 21-23; CJEU 16 September 2004, C-404/02, Nichols, EU:C:2004:538, paras. 24-28; CJEU 10 July 2014, C-421/13, Apple, EU:C:2014:2070, para. 24.

100 CJEU 18 June 2002, C-299/99, Philips, EU:C:2002:377, paras. 46-48; CJEU 6 May 2003, C-104/01, Libertel, EU:C:2003:244, para. 6; CJEU 12 February 2004, C-218/01, Henkel, EU:C:2004:88, para. 52; CJEU 29 April 2004, C-456/01, Henkel, EU:C:2004:258, para. 38; CJEU 24 June 2004, C-49/02, Heidelberger Bauchemie, EU:C:2004:384, paras. 38-40; CJEU 28 June 2004, C-445/02 P, Glaverbel, EU:C:2004:393, para. 22; CJEU 7 October 2004, C-136/02 P, Mag Instrument, EU:C:2004:592, para. 30; CJEU 12 January 2006, C-173/04 P, Deutsche SiSi-Werke, EU:C:2006:20, paras. 27-28; CJEU 22 June 2006, C-25/05 P, Storck, EU:C:2006:422, paras. 26-27; CJEU 20 October 2011, C-344/10 P and C-345/ 10 P, Freixenet, EU:C:2011:680, paras. 45-46; CJEU 12 December 2019, C-783/18 P, Wajos, EU:C:2019:1073, para. 24.

101 See Sects. 2.2.1 and 2.2.4.
} 
Nonetheless, it should not go unmentioned that the EUIPO Board of Appeal has assessed the distinctiveness of a smell on its merits. In the pre-Sieckmann era, indeed, it notably accepted "the smell of fresh cut grass" as a trade mark for tennis balls, ${ }^{102}$ and refused to register a mark consisting of "the scent of raspberries" for fuels on the basis not of a lack of representability, ${ }^{103}$ but a lack of distinctiveness. ${ }^{104}$

If, one day, the registration of smells becomes possible, it will be essential to determine on a case-by-case basis, as for other marks, whether the relevant public for the goods or services concerned considers the given smell either as an indication of origin that is functionally independent and autonomous of the product, or rather as an inherent property or a specific type or improvement of the product. ${ }^{105}$ Only in the former case will the distinctiveness criterion be met. Following trade mark practice on colour marks, ${ }^{106}$ and learning from experience in the US, ${ }^{107}$ this might sometimes mean that an olfactory mark will only meet the requirement of distinctiveness after acquiring distinctive character through use. A more-thantheoretical example would be the strong perfumes that some textile companies spray on the T-shirts that they sell. ${ }^{108}$ Requiring acquired distinctiveness should not be the standard approach, though. Some smells should indeed be held inherently capable of distinguishing certain goods or services. ${ }^{109}$ Imagine a strong sulphur scent for table cloths, for instance.

Finally, when assessing the distinctiveness of a smell, it is important not to overlook the ground for refusing and invalidating signs that consist exclusively of a characteristic that results from the nature of the goods, that is necessary to obtain a technical result, or that gives substantial value to the goods. ${ }^{110}$ Meant to guarantee that a handful of economic actors will not acquire exclusive rights to functional characteristics and technical solutions inherent to certain goods or services, these three alternative grounds for refusal and invalidity cannot be overcome by acquired distinctiveness. ${ }^{111}$ Because of this, the CJEU requires trade mark authorities and courts to test marks against this insurmountable obstacle first, even when other grounds related to a lack of distinctiveness may apply at the same time. ${ }^{112}$ As these three exclusions were redrafted in 2015 with a view to broadening their scope

\footnotetext{
$\overline{102}$ OHIM BoA 11 February 1999, R 156/1998-2, Senta Aromatic Marketing, paras. 14-15.

103 Today, the mark would be refused on the basis of the lack of objective representation; Schumacher ( 1 July 2021), para. 511.

104 OHIM BoA 5 December 2001, R 711/1999-3, Der Duft von Himbeeren.

105 See Elias (1992), p. 477; Schumacher (1 July 2021), para. 511.

106 CJEU 6 May 2003, C-104/01, Libertel, EU:C:2003:244, para. 27; EUIPO (2021), pp. 418-419.

107 See Ribeiro da Cunha and Randakeviciute-Alpman (2020), paras. 16-18.

108 Fezer (2009), MarkenG § 3, paras. 614 and 617.

109 See, however, Ribeiro da Cunha and Randakeviciute-Alpman (2020), p. 391.

110 EUTM Regulation, Art. 7(1)(e); TM Directive, Art. 4(1)(e).

111 EUTM Regulation, Arts. 7(3) and 59(2); TM Directive, Art. 4(4); CJEU 18 June 2002, C-299/99, Philips, EU:C:2002:377, paras. 74-76; CJEU 8 April 2003, C-53/01 to C-55/01, Linde, EU:C:2003:206, para. 44; CJEU 18 September 2014, C-205/13, Hauck v. Stokke and Opsvik, EU:C:2014:2233, paras. $18-20$.

112 CJEU 8 April 2003, C-53/01 to C-55/01, Linde, EU:C:2003:206, para. 44.
} 
beyond shape marks, ${ }^{113}$ it will be important to know how and to what extent they can or should be applied to smells, should the registration thereof become possible in future. Indeed, it is yet to be seen under what circumstances a smell constitutes an exclusive characteristic within its scope. Prime examples would probably be flowery aromas for perfume and cosmetic products, ${ }^{114}$ or a fresh leather smell for leather handbags.

\subsubsection{Gustatory Marks}

The findings about the distinctiveness of olfactory marks are applicable to gustatory marks mutatis mutandis. Here too, trade mark protection is currently held to be excluded according to the majority view, although there is a pre-Sieckmann decision in which the EUIPO Board of Appeal took a stance on the distinctiveness of a taste. In that case, the Board found that "the taste of artificial strawberry flavour" was not sufficiently distinctive to distinguish pharmaceutical preparations. It argued that monopolising this flavour might have anti-competitive effects, but also that consumers would most likely not perceive the taste as a trade mark but rather just as a functional means "to disguise the unpleasant taste of the product". ${ }^{115}$ Furthermore, as with olfactory marks, it is yet to be seen how to apply the ground for refusal and invalidity in respect of signs that consist exclusively of a characteristic that results from the nature of the goods, that is necessary to obtain a technical result, or that gives substantial value to the goods. Here, a trade mark application for a sweet, bitter, raspberry-like (or whatever other) taste for a foodstuff may serve as a scholarly example of excluded subject matter. ${ }^{116}$

The point has been raised that asserting the distinctiveness of tastes might be even more difficult than with smells. First, it is argued that a product's taste cannot be perceived by the relevant public prior to purchase, making very intense marketing campaigns the only path likely to pair a taste with a commercial origin. ${ }^{117}$ That argument is not convincing, though. Just as it has no bearing on a sound mark's distinctiveness whether or not it relates to "silent" goods, ${ }^{118}$ it is irrelevant whether the goods or their packaging are edible or whether they have or might have a taste. Indeed, it is for trade mark owners to determine how they will use their mark once registered.

Second, it is argued that consumers are not accustomed to perceiving tastes as indications of origin, and that they might not be able to "remember" tastes sufficiently for them to be distinctive. ${ }^{119}$ As with all types of trade marks, the distinctiveness of a taste should depend on a case-by-case analysis of whether the average consumer perceives the taste as a distinguishing sign, or merely as a

\footnotetext{
113 Hasselblatt (2018), para. 113.

114 Fezer (2009), MarkenG $\S 3$, para. 610.

115 OHIM BoA 4 August 2003, R 120/2001-2, Eli Lilly, paras. 15-16.

116 Fezer (2009), MarkenG § 3, para. 610.

117 Larrieu and Astic (2004), para. 2.

118 GC 7 July 2021, T-668/19, Ardagh Metal Beverage, EU:T:2021:420, para. 56.

119 Larrieu and Astic (2004), para. 2.
} 
functional element, though. As with olfactory marks, some gustatory marks will indeed need to acquire distinctiveness in order to be protected. Yet it is not excluded that certain tastes possess inherent distinctiveness. The latter might be true for a hot pepper-sauce taste for washing powder, for instance. Hence, the threshold for protection might well be high for certain tastes as applied to certain goods or services. Nonetheless, this is an assessment that ought to be made case by case.

\subsubsection{Tactile Marks}

As argued, it is not excluded that a touch or feel can be represented on the register with sufficient precision. ${ }^{120}$ Therefore, the distinctive character of tactile marks is less of a purely theoretical issue than it is for olfactory and gustatory marks. In 2006, the German Federal Supreme Court, for one, recognised that touch could indeed be distinctive. ${ }^{121}$ Although some have argued that the distinctiveness of touch is "generally recognised", ${ }^{122}$ it might prove difficult in certain circumstances to prove that the relevant public perceives a touch applied for as a sign that distinguishes goods or services of one undertaking from those of another. ${ }^{123}$ As with all non-traditional marks, the issue boils down to a case-specific analysis of whether the consumers perceive a given tactile feeling either as an independent indication of origin, or rather as an inherent property, a technical or functional element, or even an aesthetic component or practical feature. ${ }^{124}$

For marks that coincide with the appearance of the goods themselves or that of their packaging, the CJEU has established that only a mark "which departs significantly from the norm or customs of the sector (...) fulfils its essential function of indicating origin and is not devoid of any distinctive character", ${ }^{125}$ and that the more a sign is similar to the form in which the goods are regularly traded, the more deviation from the norm will be required. ${ }^{126}$ Put differently, the Court requires such signs to be more than just another "variant" of a common shape of the type of product in question. ${ }^{127}$ This is true for shape marks, for figurative marks consisting

\footnotetext{
120 See Sect. 2.2.3.

121 German Federal Supreme Court 5 October 2006, I ZB 73/05, 169 BGHZ 175, para. 12 - III.2.

122 Fezer (2009), MarkenG § 3, para. 622; Hanf (1 July 2021), para. 79.

123 Schoene (2006); see also German Federal PatC 23 March 2007, 26 W (pat) 3/05, 2008 GRUR 348.

124 OHIM BoA 12 March 2013, R 479/2012-5, The Procter \& Gamble Company, paras. 17 and 20-24; Schumacher (1 July 2021), para. 506.

125 CJEU 12 February 2004, C-218/01, Henkel, EU:C:2004:88, paras. 48-49; CJEU 29 April 2004, C-456/01, Henkel, EU:C:2004:258, para. 39; CJEU 12 January 2006, C-173/04 P, Deutsche SiSi-Werke, EU:C:2006:20, paras. 30-31; CJEU 22 June 2006, C-25/05 P, Storck, EU:C:2006:422, para. 28; CJEU 20 October 2011, C-344/10 P and C-345/10 P, Freixenet, EU:C:2011:680, para. 47; CJEU 12 December 2019, C-783/18 P, Wajos, EU:C:2019:1073, para. 24.

126 CJEU 29 April 2004, C-456/01, Henkel, EU:C:2004:258, para. 39; CJEU 7 October 2004, C-136/02 P, Mag Instrument, EU:C:2004:592, para. 31; CJEU 24 May 2012, C-98/11 P, Lindt, EU:C:2012:307, para. 42; CJEU 12 December 2019, C-783/18 P, Wajos, EU:C:2019:1073, para. 24; GC 24 February 2016, T-411/14, The Coca-Cola Company, EU:T:2016:94, para. 39.

127 CJEU 7 October 2004, C-136/02 P, Mag Instrument, EU:C:2004:592, para. 32; GC 24 February 2016, T-411/14, The Coca-Cola Company, EU:T:2016:94, para. 51.
} 
of the representation of a product, and for certain position marks. ${ }^{128}$ Unlike sound marks, for instance, ${ }^{129}$ tactile marks also seem to fall within the category of signs that coincide with the appearance of goods or their packaging. Hence, it is arguable that tactile marks also need to meet the standard of a substantial departure from the norms and customs, at least when they are applied to a product or its packaging.

The EUIPO Board of Appeal applied that standard in a 2013 case about the "multisensorial tactile feeling" of a certain toothbrush grip, submitted for toothbrushes, described as "the tactile contrast between the ribs, made of soft rubber but rough to the touch... and the round hard plastic pearl...". The Board held that consumers did not usually notice slight differences between different toothbrush grips and that it was not common to recognise the commercial origin of a toothbrush on the basis of the feeling of its handgrip. It therefore concluded that consumers would conceive the submitted "touch and feel" as just another variant of common handle grips. As the variant applied for did not significantly depart from the norm or customs, the application was refused. ${ }^{130}$

Not unlike the EUIPO, the German Federal Patent Court has proven very reluctant to grant trade mark protection to tactile signs, despite the theoretical possibility to do so under German national trade mark law. Although its judgment on "the raw feeling of fine sand paper", as applied to beer bottles, was mainly decided on the basis of the representation criterion, the Court additionally considered that consumers would not be able to recognise the surface of a bottle as an indication of commercial origin. ${ }^{131}$ Commentators have rightfully pointed out that this view is excessively restrictive. Indeed, it is difficult to see why average consumers would not be able to identify the origin of a beer on the basis of the feeling of a sandpaper surface applied to the bottle. ${ }^{132}$ There is a principle of EU trade mark law that states that marks should not be subjected to either different or more or less strict criteria for protection on the basis of their type. ${ }^{133}$ Against that background, the German Court's finding seems hard to justify.

\subsubsection{Remarks}

The requirement of distinctiveness seems to constitute far less a hurdle to the successful registration of the three non-visual trade marks in question than the representability requirement, at least in theory and de lege lata. Nonetheless, it

\footnotetext{
128 CJEU 12 February 2004, C-218/01, Henkel, EU:C:2004:88, paras. 48-49; CJEU 29 April 2004, C-456/01, Henkel, EU:C:2004:258, para. 39; CJEU 7 October 2004, C-136/02 P, Mag Instrument, EU:C:2004:592, para. 32; CJEU 12 January 2006, C-173/04 P, Deutsche SiSi-Werke, EU:C:2006:20, paras. 30-31; CJEU 22 June 2006, C-25/05 P, Storck, EU:C:2006:422, paras. 28-29; CJEU 20 October 2011, C-344/10 P and C-345/10 P, Freixenet, EU:C:2011:680, paras. 47-48; CJEU 24 May 2012, C-98/ 11 P, Lindt, EU:C:2012:307, para. 42; CJEU 10 July 2014, C-421/13, Apple, EU:C:2014:2070, para. 20; CJEU 12 December 2019, C-783/18 P, Wajos, EU:C:2019:1073, para. 24.

129 GC 7 July 2021, T-668/19, Ardagh Metal Beverage, EU:T:2021:420, paras. 31-33.

130 See OHIM BoA 12 March 2013, R 479/2012-5, The Procter \& Gamble Company, paras. 26-32.

131 German Federal PatC 23 March 2007, 26 W (pat) 3/05, 2008 GRUR 348, para. II.2.

132 Ingerl and Rohnke (2010), MarkenG $\S 8$, para. 194.

133 See fn. 101.
} 
remains to be seen to what extent the average consumer will one day actually recognise commercial origin by reference to smell, taste and feel in practice.

In this respect, it has been rightly pointed out in relation to smells that, although consumers might well "recognise" a smell and connect it to a certain brand, an olfactory mark will always be accompanied by other indicators of origin that are stronger. ${ }^{134}$ Moreover, consumers will indeed still keep using words as the common way to refer to commercial origin. Just as very few consumers are likely to say that they bought shoes of the "three-stripe mark" rather than just mentioning Adidas, for instance, it is equally unlikely that they would refer to "the raspberry-smell company" or "that washing powder with the packaging that tastes like hot chili sauce", or say that they had bought a new "sandpaper bottle beer". Indeed, it is debatable whether consumers would sufficiently notice and put trust in solely a certain smell, taste, feeling or other non-traditional mark to decide whether to purchase a product. In most cases, these non-traditional signs will only be truly perceived as commercial indicators when used in combination with other signs. ${ }^{135}$

Although this may be true, it does not diminish the fact that the three signs under investigation can meet the trade mark requirement of distinctiveness, which is to be assessed in concreto. Given the various ways in which trade marks can be used, it is reasonable to imagine that consumers might become accustomed to linking commercial advertisements with a specific rough texture, with a raspberry smell, or even with a hot-pepper taste to an undertaking, for instance. Moreover, the combination of different signs and types of sign present may increase consumer trust in the authenticity of a product. A shoe that only contains a word mark or an olfactory mark might indeed be perceived as more likely to be counterfeit than a shoe that contains a word mark, two figurative marks, a position mark and an olfactory mark, if they are all held by the same undertaking.

\section{Scope of Protection}

Although the exact reach of the rights of a trade mark owner should lie at the heart of the discussion about a sign's protectability, the potential scope of protection of non-traditional marks appears to be hardly investigated. ${ }^{136}$ Admittedly, the potential protection granted by olfactory and gustatory marks currently remains a purely theoretical topic in the EU, for smells and tastes are not considered capable of being represented on the register hic et nunc. Similarly, it is yet to be seen whether tactile marks will actually make it to the register. This does not diminish the fact that interesting findings may follow from an analysis of what might constitute a trade mark infringement de lege ferenda if they can one day be registered, though.

Pursuant to harmonised EU legislation, a trade mark infringement will only arise if, preliminarily, an infringer uses the mark "in the course of trade, in relation to

\footnotetext{
134 Elias (1992), p. 483.

135 Cf. Blum and Cullen (2014), p. 1010; Ghidini (2018), pp. 215-216.

136 Handler (2018), p. 166.
} 
goods or services". ${ }^{137}$ The importance of this preliminary criterion can hardly be underestimated in relation to non-traditional marks. Given the logical premise that trade mark rights can only be invoked to bring a halt to cases where a sign is used to create an impression on targeted consumers that there is a material link in trade between the trade mark holder and the goods bearing the sign, ${ }^{138}$ courts and trade mark authorities should perform a case-by-case analysis, proceed with prudence and even exercise restraint when faced with an action for infringement for nontraditional marks. Indeed, not every use of a sign will constitute a protected use "as a trade mark", i.e. to distinguish goods or services as originating from a particular undertaking. ${ }^{139}$ Just as the holder of a colour trade mark should not be allowed to prevent competitors from using doorknobs or toilet paper in that colour in their stores, the scope of an olfactory, gustatory, or tactile mark should not extend over merely anything that has a link with the product concerned. Trade mark law applies only when the smell, taste, or feeling can actually be perceived by consumers as an indication of origin.

Save this important prerequisite, non-visual trade marks will probably not cause substantial issues with respect to precise imitation, i.e. where someone uses an identical sign for goods or services that are identical with those for which registration has been obtained. ${ }^{140}$ By contrast, the crux lies, on the one hand, in determining when a smell, taste or feeling is sufficiently "similar" to a registered sign and correspondingly causes a likelihood of confusion leading to an infringement other than precise imitation ${ }^{141}$ and, on the other hand, in determining the societal and economic consequences of that infringement.

First, there is a likelihood of confusion when there is a "risk that the public might believe that the goods or services in question come from the same undertaking or, as the case may be, from economically linked undertakings". ${ }^{142}$ According to the CJEU, the similarity of two signs must notably be determined on a case-by-case basis, taking into account "the degree of visual, aural or conceptual similarity between them" in the eyes of the average consumer, whereby courts must "evaluate the importance to be attached to those different elements, taking account of the category of goods or services in question and the circumstances in which they are marketed". ${ }^{143}$ Yet how should one apply that case-law to signs that are neither visual nor audible? At the centre of this vexed issue lies the uncertainty about how and to what extent consumers, courts and trade mark offices can actually compare

\footnotetext{
${ }^{137}$ EUTM Regulation, Art. 9(2); TM Directive, Art. 10(2) and Recital 18; cf. CJEU 12 July 2011, C-324/ 09, L'Oréal, EU:C:2011:474, para. 54.

138 CJEU 16 November 2004, C-245/02, Anheuser-Busch, EU:C:2004:717, paras. 59-60.

139 CJEU 23 February 1999, C-63/97, BMW, EU:C:1999:82, para. 38.

${ }^{140}$ EUTM Regulation, Art. 9(2)(a); TM Directive, Art. 10(2)(a).

141 See EUTM Regulation, Art. 9(2)(b)-(c); TM Directive, Art. 10(2)(b)-(c).

142 CJEU 29 September 1998, C-39/97, Canon, EU:C:1998:442, para. 29; CJEU 22 June 1999, C-342/97, Lloyd, EU:C:1999:323, para. 17.

143 CJEU 11 November 1997, C-251/95, Sabel, EU:C:1997:528, para. 23; CJEU 22 June 1999, C-342/97, Lloyd, EU:C:1999:323, para. 27; CJEU 3 September 2009, C-498/07 P, Aceites del Sur-Coosur, EU:C:2009:503, paras. 60-61; CJEU 18 July 2013, C-252/12, Specsavers, EU:C:2013:497, para. 35; CJEU 16 January 2019, C-162/17 P, Stock Polska, EU:C:2019:27, para. 41.
} 
and remember different smells, tastes and feels with sufficient detail. ${ }^{144}$ This is a scientific rather than a legal question. For want of precise terminology, it seems indeed very hard to objectively determine similarities between two smells, tastes and feels. ${ }^{145}$

To mitigate this absence of objective parameters, Schrader suggests that more relevance should be attributed to the verbal descriptions included in the trade mark applications for non-verbal signs. Similar to the claims section in patent applications, those descriptions could indicate why the sign is distinctive and thus delineate the mark's scope of application. ${ }^{146}$ This approach would require a change in trade mark practice in the EU though, as the scope of a trade mark first and foremost depends on the representation disclosed within the European trade mark system. Conversely, additional verbal descriptions may be used only to clarify that representation, not to extend its scope or to deviate from the representation disclosed. ${ }^{147}$ If the strict focus on the representation disclosed is relaxed, then the approach suggested by Schrader may prove an interesting way forward, at least if combined with corresponding digital search functions that allow users to search through the registers on the basis of keywords.

Second, the potential societal and economic impact of granting trade mark protection to smells, tastes and feels should not be left unexplored. In this respect, it should be pointed out that the CJEU requires a trade mark and an allegedly infringing sign to be compared from the viewpoint of a "reasonably well-informed and reasonably observant and circumspect" average consumer of the products concerned, whereby "account should be taken of the fact that the average consumer only rarely has the chance to make a direct comparison between the different marks but must place his trust in the imperfect picture of them that he has kept in his mind". ${ }^{148}$ Therefore, the CJEU has remarked, in its case-law on single-colour trade marks, that it is irrelevant whether current technology allows a very wide range of shades of colour to be identified. As assessments will often start from the "imperfect picture" in the mind of the members of the public and "the number of colours which that public is capable of distinguishing is limited", "[i]t follows that the number of different colours that are in fact available as potential trade marks to distinguish goods or services must be regarded as limited". ${ }^{149}$ As a result of the potential to confuse shades, two non-identical colours will often be found similar, and the whole spectrum of colours might soon be entirely depleted by just a limited number of registrations.

In relation to colour marks, scholars have warned that, given the standard of the "imperfect picture" in the assessment of infringements, a mere handful of

\footnotetext{
144 Cf. Ribeiro da Cunha and Randakeviciute-Alpman (2020), p. 395.

145 Elias (1992), pp. 487 and 490-491; Schneider (2018), para. 49.

146 Schrader (2007), pp. 152-153.

147 See fn. 61.

148 CJEU 22 June 1999, C-342/97, Lloyd, EU:C:1999:323, para. 26; cf. CJEU 6 May 2003, C-104/01, Libertel, EU:C:2003:244, para. 64.

149 Id. C-104/01, paras. 45 and 47.
} 
undertakings could successfully foreclose the market in their sector. ${ }^{150} \mathrm{~A}$ small number of economic actors could even monopolise the use of a certain colour in the entire economy if they could prove that their colour mark had a reputation and that third parties' usage of a similar colour either amounted to freeriding or caused dilution. ${ }^{151}$ One illustration of the potential reach of colour marks is a judgment by the German Federal Supreme Court in which the scope of a yellow single-colour mark for bilingual paper dictionaries was found to extend over language-teaching computer programs. ${ }^{152}$

These findings about colours raise the question whether similar concerns apply to olfactory, gustatory, and tactile marks. At first sight, it seems that the human mind should be able to memorise, recognise and distinguish a bigger variety of smells, tastes and feels than colours, but is that so ${ }^{153}$ If not, then submitting them for trade mark protection risks leading to the complete commercialisation of all our senses. ${ }^{154}$ From a normative perspective, it is therefore advisable to conduct more in-depth research on these three senses.

\section{Remarks}

Overall, the protection of non-visual trade marks is a topic subject to a rather blurry debate. Descriptive (de lege lata) and normative (de lege ferenda) arguments are sometimes used interchangeably, for instance by highlighting potential doom scenarios that may result from applying current legislation to non-traditional marks. Moreover, positions on the topic are very much dependent on the level of detail one can expect of representations, as well as on what we lawyers think is either possible or impossible from a practical and technological perspective.

Keeping US experience in mind, it has been argued that the protection of all sorts of non-traditional signs will be inevitable. Desai notes that when marketeers start "branding" products by using a certain type of sign, the law will have no choice other than to follow that trend in the long run. ${ }^{155}$ Indeed, the persistence of big economic players will probably always pay off in the end, which is regretted by Carboli. ${ }^{156}$ Sharing this eminent scholar's concerns, other authors have likewise argued that trade mark protection for every possible type of sign might lead to the overprotection and depletion of all signs, and risks resulting in a situation where just about everything can or will be subject to propertisation. ${ }^{157}$

Not all non-visual trade marks are equal. Whereas sound marks are becoming more and more established in the EU, the analysis above has shown that olfactory

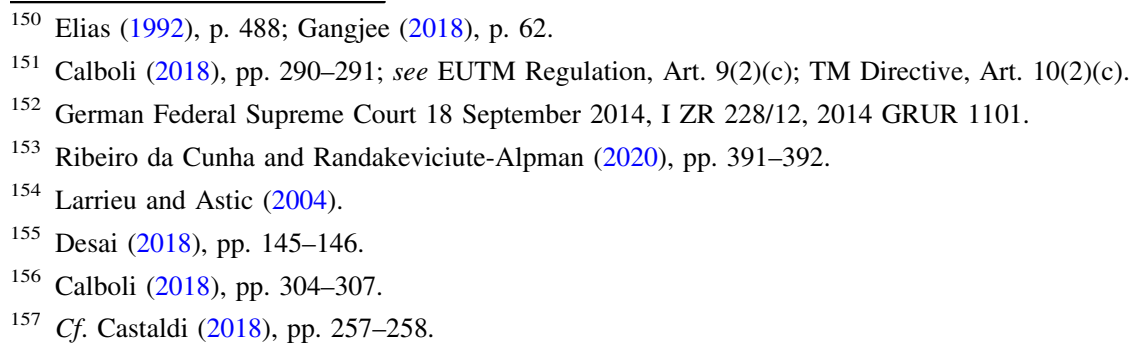


and gustatory marks are excluded by an apparent lack of Sieckmann-compliant ways of representing them on the register. European trade mark offices also seem to exclude the registration of tactile marks on the same grounds, although this resolute stance is open for criticism. If these three marks will be registrable one day, it still remains to be seen how far their scopes of application will reach in practice. In short, marks that are neither visible nor audible are having a hard time in the EU.

Reading through the decisions on applications for the three types of mark under investigation, one cannot avoid the impression that trade mark offices and courts are essentially very reluctant to grant protection to non-visible, non-audible signs. This is especially true for tactile marks. In this respect, the lengthy considerations of the German Federal Patent Court's judgment on the application for a mark consisting of "the raw feeling of fine sand paper" as applied to beer bottles, are emblematic. ${ }^{158}$ Dismissing each and every argument on representability and even on distinctiveness, without giving any hints on acceptable alternatives, the Court seemingly wants to avoid trade mark protection of touch at any cost.

Similarly, there is the oft-read argumentation that an applicant has failed to prove that its sign is used as an indication of commercial origin in the course of trade. The OHIM Board of Appeal for instance refused protection to a tactile mark, arguing that "there are no tactile marks on OHIM's register and this fact speaks against registration". This argumentation is circular, as registration ought to be the formal result of meeting all criteria for trade mark protection, and not a prerequisite for protection. "As to the argument that companies are constantly trying to develop new ways to distinguish their goods", the Board laconically held that "this may be true, but it does not follow that all those ways are successful or registrable as trade marks". ${ }^{159}$ Looking beyond the actual reasoning upheld in these and similar decisions, it sometimes looks as if authorities and the judiciary essentially try to avoid opening Pandora's box, which they fear might happen if they allowed new non-traditional signs to be protected.

If it is true that judges and officers are essentially avoiding recognising certain types of marks, then perhaps there are good reasons for that. Indeed, it seems defensible to argue that there is some kind of shared uncodified legal feeling that it would just be a step too far to protect certain subject matter by intellectual property - an implicit Freihaltebedürfnis for smells, taste and especially touch, so to speak. Although this argument may have great relevance de lege ferenda, the EU's current trade mark legislation leaves little space for its application, ${ }^{160}$ in particular due to the equal treatment to which different types of marks should be subjected when their distinctive character is being assessed. ${ }^{161}$ In other words, applicants are entitled to have even the most uncommon type of sign registered as a mark as long as it complies with the conditions for protection, even if the potential economic or

\footnotetext{
158 German Federal PatC 23 March 2007, 26 W (pat) 3/05, 2008 GRUR 348.

159 OHIM BoA 12 March 2013, R 479/2012-5, The Procter \& Gamble Company, paras. 33-34.

160 Cf. CJEU 8 April 2003, C-53/01 to C-55/01, Linde, EU:C:2003:206, para. 75.

161 See fn. 101.
} 
societal impact of allowing registrations of the new types of sign in question are to be feared. ${ }^{162}$

Some solutions have been put forward to balance the protectability of nontraditional signs with economic and societal needs de lege lata. One path would consist in overriding any undesirable results of trade mark law by reference to fundamental rights. Referring to the freedom of expression or the freedom to conduct a business, courts could thus proceed to a case-based balancing of interests and, for instance, allow trade mark uses that would otherwise have been qualified as infringement. ${ }^{163}$ In relation to copyright, the CJEU has excluded the possibility of referring to fundamental rights as "external" limitations that complement the limitations explicitly consolidated in harmonised EU law. ${ }^{164}$ It has not yet produced similar case-law on trade marks. Interestingly, trade mark legislation explicitly lays down that it "should be applied in a way that ensures full respect for fundamental rights and freedoms, and in particular the freedom of expression". ${ }^{165}$ Thus it seems to leave more leeway than copyright law.

As an alternative path, one could envisage certain signs being refused or invalidated for being contrary to public policy or to accepted principles of morality. ${ }^{166}$ A stronger implementation of this "internal" limitation would not only have effects for non-traditional signs but could equally apply to other cases where it is felt that a sign needs to be kept free for everyone to use. As an illustration in this respect, reference can be made to the EUIPO's declaration that it would refuse registration of signs consisting of "Je suis Charlie" on the basis of public policy. ${ }^{167}$

The main weakness of these internal and external limitations as a means of balancing the protectability of all signs with the need to keep certain matter out of the scope of trade mark law is that they both open the door to arbitrary outcomes. Indeed, an overly liberal reading of a norm as open as "public policy" entails the risk that economic actors will face even more legal uncertainty in relation to nontraditional trade marks. Against this background, it is submitted that current law does not preclude the valid registration of whatever type of representable sign as a trade mark, but that it is up to the lawmaker to address the emerging questions of the protectability of non-traditional signs de lege ferenda. In conclusion, it pertains to the EU legislature's discretion to determine whether there is an actual socioeconomic need to exclude certain signs or types of signs from the scope of trade mark law in future.

\footnotetext{
162 Cf. Fezer (2009), MarkenG § 3, para. 608.

163 Cf. Handler (2018), p. 183.

164 CJEU 29 July 2019, C-469/17, Funke Medien, EU:C:2019:623, paras. 62-64; CJEU 29 July 2019, C-476/17, Pelham, EU:C:2019:624, paras. 59-65; CJEU 29 July 2019, C-516/17, Spiegel Online, EU:C:2019:625, paras. 47-49; see, prior to these decisions, van Deursen and Snijders (2018), pp. 1096-97; and for criticism, Dreier (2019), pp. 1005 and 1006; Geiger and Izyumenko (2020), pp. 298-303.

165 EUTM Regulation, Recital 21, last sentence; TM Directive, Recital 27, last sentence.

166 EUTM Regulation, Art. 7(1)(f); TM Directive, Art. 4(1)(f).

167 See OHIM (16 January 2015) Je suis Charlie - acceptability by OHIM of any potential applications. https://euipo.europa.eu/ohimportal/nl/news/-/action/view/1787585. Accessed 8 September 2021.
} 
Funding Open Access funding enabled and organized by Projekt DEAL. This paper was made possible by funding from both the FWO Research Foundation - Flanders (scholarship No. 12V3220N) and the Max Planck Institute for Innovation and Competition.

Open Access This article is licensed under a Creative Commons Attribution 4.0 International License, which permits use, sharing, adaptation, distribution and reproduction in any medium or format, as long as you give appropriate credit to the original author(s) and the source, provide a link to the Creative Commons licence, and indicate if changes were made. The images or other third party material in this article are included in the article's Creative Commons licence, unless indicated otherwise in a credit line to the material. If material is not included in the article's Creative Commons licence and your intended use is not permitted by statutory regulation or exceeds the permitted use, you will need to obtain permission directly from the copyright holder. To view a copy of this licence, visit http:// creativecommons.org/licenses/by/4.0/.

\section{References}

Blum J, Cullen A (2014) The Apple store and unconventional trade marks: how easy are they to enforce? JIPLP 1008-1011

Calboli I (2018) Hands off "my" colors, patterns, and shapes! How non-traditional trademarks promote standardization and may negatively impact creativity and innovation. In: Calboli I, Sentfleben MRF (eds) The protection of non-traditional trademarks: critical perspectives. OUP, Oxford

Castaldi C (2018) The economics and management of non-traditional trademarks. In: Calboli I, Sentfleben MRF (eds) The protection of non-traditional trademarks: critical perspectives. OUP, Oxford

Desai D (2018) Should trademark law protect non-traditional trademarks? In: Calboli I, Sentfleben MRF (eds) The protection of non-traditional trademarks: critical perspectives. OUP, Oxford

Dreier T (2019) Grundrechte und die Schranken des Urheberrechts. GRUR 1003-1008

Durrande S, Canlorbe J (22 June 2021) Fasc. 7100. Différents signes susceptibles de constituer une marque. JurisClasseur Marques - Dessins et modèles. LexisNexis

Elias B (1992) Do scents signify source? An argument against trademark protection for fragrances. Articles and Reports. Trademark Rep 82:475-530

EUIPN (2018/19) Common communication on the representation of new types of trade marks. CC8. 10 p. https://euipo.europa.eu/tunnel-web/secure/webdav/guest/document_library/contentPdfs/about_ euipo/who_we_are/common_communication/common_communication_8/common_ communication8_en.pdf. Accessed 9 Sept 2021

EUIPN (April 2021) Common practice. new types of marks: examination of formal requirements and grounds for refusal. CP11. 65 p. https:/euipo.europa.eu/tunnel-web/secure/webdav/guest/ document_library/contentPdfs/EUIPN/CP11/common_communication_cp11_en.pdf. Accessed 9 Sept 2021

EUIPO (2021) [Trade Mark] Guidelines for examination. 1610 p. https://euipo.europa.eu/ohimportal/en/ guidelines. Accessed 9 Sept 2021

Fezer K-H (2009) Markenrecht. Beck'sche Kurz-Kommentare. Beck, Munich

Fields D, Muller A (2017) Going against tradition: the effect of eliminating the requirement of representing a trade mark graphically on applications for non-traditional marks. EIPR 39:238-243

Gangjee DS (2018) Paying the price for admission: non-traditional marks across registration and enforcement. In: Calboli I, Sentfleben MRF (eds) The protection of non-traditional trademarks: critical perspectives. OUP, Oxford

Geiger C, Izyumenko E (2020) The constitutionalization of intellectual property law in the EU and the Funke Medien, Pelham and Spiegel Online Decisions of the CJEU: Progress, but still some way to go! IIC 282

Ghidini G (2018) The protection of (three-dimensional) shape trademarks and its implications for the protection of competition. In: Calboli I, Sentfleben MRF (eds) The protection of non-traditional trademarks: critical perspectives. OUP, Oxford

Handler M (2018) What should constitute infringement of a non-traditional mark? The role of "trademark use." In: Calboli I, Sentfleben MRF (eds) The protection of non-traditional trademarks: critical perspectives. OUP, Oxford 
Hanf D (1 July 2021) [UMV 2017] Art. 7. Absolute Eintragungshindernisse. Unterscheidungskraft einzelner Markenformen. In: Kur A, von Bomhard V, Albrecht F (eds) Beck'sche OnlineKommentare Markenrecht. Beck, Munich

Hasselblatt GN (2018) Article 7. Absolute grounds for refusal. In: Hasselblatt GN (ed) European Union Trade Mark Regulation article-by-article commentary. Beck, Munich

Ingerl R, Rohnke C (2010) Markengesetz. Beck, Munich

Janssens M (2019) Handboek merkenrecht. Intersentia, Antwerpen

Larrieu J, Astic V (2004) Du lèche-vitrines au lèche-marques. Dalloz 2433-2437

Max Planck Institute for Intellectual Property and Competition Law (2011) Study on the overall functioning of the European trade mark system. XI+278 p. https://op.europa.eu/s/pBi7. Accessed 9 Sept 2021

Pauwels J (2016) Exploiting prior knowledge during automatic key and chord estimation from musical audio. Thesis defended to obtain the title of Doctor in Engineering Ghent, Ghent University, XXIV+185 p. https://lib.ugent.be/catalog/pug01:8039246. Accessed 9 Sept 2021

Ribeiro da Cunha I, Randakeviciute-Alpman J (2020) New types of marks available after the European Union Trade Mark reform. An analysis in the light of the U.S. Trademark Law. JIPITEC 375-397

Schneider G (2018) Article 4. Signs of which an EU trade mark may consist. In: Hasselblatt GN (ed) European Union Trade Mark Regulation article-by-article commentary. Beck, Munich

Schoene V (2006) BGH: Über den Tastsinn wahrnehmbares Zeichen kann als Marke eingetragen werden. FD-GewRS 204253

Schrader P (2007) Beschreibung des Schutzgegenstands bei Anmeldung einer Tastmarke. GRUR $152-153$

Schumacher J (1 July 2021) [MarkenG] Sonstige Markenformen. In: Kur A, von Bomhard V, Albrecht F (eds) Beck'sche Online-Kommentare Markenrecht. Beck, Munich

USPTO (2021) Trademark manual of examining procedure. https://www.uspto.gov/trademarks/guidesand-manuals/tmep-archives. Accessed 9 Sept 2021

van Deursen S, Snijders T (2018) The Court of Justice at the crossroads: clarifying the role for fundamental rights in the EU copyright framework. IIC 1080-1097

Voßberg T (2021) Hör mal, wer da zischt und prickelt - zur fehlenden Unterscheidungskraft einer Geräuschmarke für Getränke. GRUR-Prax 438

Wee Loon N-L (2018) Absolute bans on the registration of product shape marks: a breach of international law? In: Calboli I, Sentfleben MRF (eds) The protection of non-traditional trademarks: critical perspectives. OUP, Oxford

Zhan Q (2017) The international registration of non-traditional trademarks: compliance with the TRIPS Agreement and the Paris Convention. World Trade Rev 16:111-140

Publisher's Note Springer Nature remains neutral with regard to jurisdictional claims in published maps and institutional affiliations. 